УдК 633.112.9+631.81.095.337

DOI 10.36461/NP.2020.54.1.005

\title{
ЭФФЕКТИВНОСТЬ НЕКОРНЕВОЙ ПОДКОРМКИ МИКРОЭЛЕМЕНТНЫМИ УДОБРЕНИЯМИ НА УРОЖАЙНОСТЬ И КАЧЕСТВО ЗЕРНА ЯРОВОЙ ТРИТИКАЛЕ
}

\author{
А. Н. Кшникаткина, доктор с.-х. наук, профрессор; А. Н. Долженко, аспирант \\ Федеральное государственное бюджетное образовательное учреждение \\ высшего образования Пензенский государственный аграрный университет, Россия, \\ т. (8412)62-81-51; e-mail: pererabotka_tehfak@mail.ru
}

Представлены результаты исследований по влиянию микроэлементных удобрений на формирование урожайности и качество зерна яровой тритикале сорта Укро. Установлено, что микроэлементные удобрения Азосол 36 Экстра, Мегамикс-Азот, Мегамикс-Профи, Цитовит и НаноКремний обеспечили увеличение параметров фотосинтеза агроценозов яровой тритикале. Максимальное значение листовой поверхности 42,5 тыс. ${ }^{2} /$ га, фотосинтетического потенциала 1,03 млн. м² дн./га, чистой продуктивности фотосинтеза $6,29 \mathrm{r}^{2} \mathrm{~m}^{2}$ в сутки отмечены при двукратной фолиарной подкормке в фразы кущения и колошения препаратом Азосол 36 Экстра. Вследствие применения некорневой подкормки растений микроэлементными удобрениями в хелатной форме наблюдалось повышение урожайности яровой тритикале сорта Укро в совокупности с улучшением технологических свойств зерна. По вариантам опыта, в среднем за три года, урожайность зерна была 3,84-4,43 т/га. Прибавка по отношению к контролю колебалась в пределах 0,42-1,27 т/га (13,3-40,3 \%). Наибольшая урожайность высококачественного зерна 4,43 т/га получена при двукратной подкормке в фазы кущения и колошения препаратом Азосол 36 Экстра, прибавка урожая зерна 1,27 т/га (40,3 \%), натура зерна 796 г/л, стекловидность - 63 \%, сырая клейковина - 26,2 \%, белка - 15,1\%.

Ключевые слова: яровая тритикале, микроэлементные удобрения, фотосинтез, урожайность, технологические свойства зерна.

\section{Введение}

Важнейший показатель продовольственной безопасности России - производство высококачественного продовольственного и кормового зерна [1]. Одним из способов решения данной проблемы является максимальная реализация генетического потенциала высокой урожайности перспективных зерновых культур. Одной из таких является тритикале, поскольку она характеризуется высоким потенциалом продуктивности и качеством зерна, устойчивостью к неблагоприятным почвенно-климатическим условиям и болезням. Тритикале используется в народном хозяйстве как зернофуражная, продовольственная и кормовая культура [2-5].

Инновационные технологии производства зерновых культур предусматривают использование комплексных удобрений с микроэлементами в хелатной форме. Они легко занимают определенную нишу в технологии возделывания сельскохозяйственной культуры. Процесс управления онтогенезом растений с помощью физиологически активных веществ дает возможность направленно воздействовать на отдельные этапы развития с целью полной реализации генетического потенциала раститель- ного организма. Именно это способствует повышению продуктивности растений, тем самым повышая устойчивость растений к стрессовым воздействиям, фритопатогенам, особенно проявляющихся при нехватке важных микроэлементов в почве [6-9].

Растениям на протяжении всего периода вегетации необходимо микроэлементное питание. Максимальная же потребность в нем отмечается в период образования органов репродукции, при цветении и оплодотворения.

Ф. Ф. Мацков (1957) утверждает, что применением подкормок вегетирующих растений мы способствуем усилению ослабленных звеньев питания, по своему желанию изменяем направленность работы фрерментов и характер внутриклеточного обмена. В результате ростом и развитием растительного организма возможно управлять, как и управлять процессом образования урожая [10].

Г. К. Самохвалов (1955) и Н. С. Авдонин (1960) также утверждают, что подкормка вегетирующих растений не утратит своего важного значения при правильной системе удобрения [11-12].

В связи с этим возникает необходимость В научном обосновании применения 
Фотосинтетическая деятельность агроценозов яровой тритикале сорта Укро

(среднее за 2017-2019 ге.)

\begin{tabular}{|c|c|c|c|c|}
\hline $\begin{array}{c}\text { Фактор A - } \\
\text { препарат }\end{array}$ & $\begin{array}{c}\text { Фактор В - } \\
\text { фаза обработки }\end{array}$ & $\begin{array}{c}\text { Площадь листьев, } \\
\text { тыс. м²/га }\end{array}$ & $\begin{array}{c}\Phi П, \\
\text { млн. м²дн./га }\end{array}$ & $\begin{array}{c}\text { ЧПФ, } \\
\text { г/м² в сутки }\end{array}$ \\
\hline \multicolumn{2}{|c|}{ Без обработки (контроль) } & 32,3 & 0,78 & 4,78 \\
\hline \multirow{3}{*}{$\begin{array}{l}\text { Азосол } 36 \\
\text { Экстра }\end{array}$} & Кущение & 36,3 & 0,88 & 5,38 \\
\hline & Колошение & 39,8 & 0,95 & 5,89 \\
\hline & Кущение + колошение & 42,5 & 1,03 & 6,29 \\
\hline \multirow{3}{*}{$\begin{array}{l}\text { Мегамикс- } \\
\text { Азот }\end{array}$} & Кущение & 36,0 & 0,87 & 5,34 \\
\hline & колошение & 39,2 & 0,95 & 5,80 \\
\hline & Кущение + колошение & 41,8 & 1,01 & 6,18 \\
\hline \multirow{3}{*}{$\begin{array}{l}\text { Мегамикс- } \\
\text { Профри }\end{array}$} & Кущение & 35,6 & 0,86 & 5,27 \\
\hline & Колошение & 38,6 & 0,94 & 5,72 \\
\hline & Кущение + колошение & 40,7 & 0,98 & 6,01 \\
\hline \multirow{3}{*}{ Цитовит } & Кущение & 35,1 & 0,85 & 5,20 \\
\hline & Колошение & 37,2 & 0,91 & 5,51 \\
\hline & Кущение + колошение & 39,2 & 0,95 & 5,80 \\
\hline \multirow{3}{*}{$\begin{array}{l}\text { Нано- } \\
\text { Кремний }\end{array}$} & Кущение & 36,2 & 0,86 & 5,34 \\
\hline & Колошение & 39,3 & 0,93 & 5,83 \\
\hline & Кущение + колошение & 41,8 & 1,01 & 6,25 \\
\hline
\end{tabular}

комплексных микроэлементных удобрений в технологии возделывания яровой тритикале.

\section{Методы и материалы}

Исследования по определению эффективности комплексных удобрений с микроэлементами в хелатной фрорме для некорневой подкормки посевов яровой тритикале проводились в 2017-2019 гг. в агрофрирме «Биокор-С» Мокшанского района Пензенской области. Почва опытного участка чернозем выщелоченный, среднегумусный, среднемощный, тяжелосуглинистый. Содержание гумуса в пахотном слое - 6,5\%, подвижного фосффора - 10,3 мг/кг почвы, обменного калия - 16 мг/кг почвы, обеспеченность подвижными формами молибдена, бора, марганца, меди, цинка и кобальта - низкая, реакция почвенного раствора слабокислая (рН 5,4). Объект исследований - яровая тритикале сорт Укро. Предшественник - клевер паноннский, норма высева - 4 млн. всхожих семян на гектар.

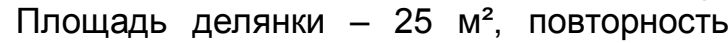
трехкратная, размещение делянок систематическое. Минеральные удобрения $\mathrm{N}_{60} \mathrm{P}_{60} \mathrm{~K}_{60}$ вносили под предпосевную культивацию. Учет урожая сплошной поделяночный, приводили к $14 \%$ влажности. Опыт закладывался в соответствии с общепринятыми методиками [13] по схеме: Фактор A - препараты: Азосол 36 Экстра 4 л/га; Мегамикс-Азот 2 л/га; МегамиксПрофи 1 л/га, Цитовит 1 л/га, НаноКремний 200 г/га. Фактор В - сроки некорневой обработки: фаза кущения, колошения, кущения + колошения. Схема: 1. Без обработки (контроль); 2. Некорневая подкормка Азо- сол 36 Экстра в фазу кущения; 3. Азосол 36 Экстра в фразу колошения; 4. Азосол 36 Экстра в фразу кущения + колошения; 5. Мегамикс-Азот в фразу кущение; 6. Мегамикс-Азот в фазу колошения; 7. МегамиксАзот в фразу кущения + колошения; 8. Мегамикс-Профи в фразу кущения; 9. Мегамикс-Профи в фразу колошения; 10 Мегамикс-Профи в фразу кущения + колошения; 11. Цитовит в фазу кущения; 12. Цитовит в фазу колошения; 13. Цитовит в фразу кущения + колошения; 14. НаноКремний в фазу кущения; 15. НаноКремний в фазу колошения; 16. НаноКремний в фразу кущения + колошения.

\section{Результаты}

Показатели фотосинтеза растений в посевах являются важнейшими факторами, определяющими формирование сельскохозяйственных культур. Площадь ассимилирующей поверхности, сроки ее функционирования и продуктивность фотосинтеза в большей мере обуславливают величину урожая [14-16].

И. С. Шатилов и другие авторы (1979) утверждают, что листьям принадлежит ведущая роль в процессе фотосинтеза, что определено филогенезом самого растения. Из всей поглощенной растительным покровом энергии на долю листьев приходится 80-90\%, остальная часть принадлежит стеблям, ветвям и другим зеленым органам [17].

Установлено, что активность фотосинтетической деятельности агроценозов яровой тритикале сорта Укро зависит от вида препарата и срока некорневой подкормки. Комплексные удобрения с микроэлемента- 
ми в хелатной форме при подкормке вегетирующих растений в фазу кущения, колошения способствуют увеличению параметров фотосинтеза яровой тритикале сорта Укро. Во все годы исследований четко прослеживается наиболее интенсивное увеличение листовой поверхности в фазу колошения яровой тритикале (табл. 1). При проведении подкормки яровой тритикале в фазу кущения площадь листьев по вариан-

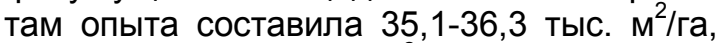
контроль - 32,3 тыс. м²/га. При листовой подкормки в фазу колошения ассимилирующая поверхность посевов тритикале увеличилась до $37,2-42,5$ тыс. $\mathrm{m}^{2} / г а$, что превышает показатели контрольного варианта на 4,9-7,5 тыс. м²/га или 11,5-23,2\%. Наибольшая листовая поверхность агроценозов тритикале сорормировалась при двукратной некорневой подкормке микроэлементными удобрениями в фазу кущения и колошения и составила по вариантам

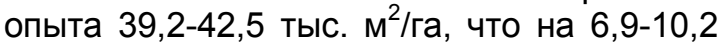
тыс. $\mathrm{m}^{2} /$ га $(18,8-31,6 \%)$ превышает контроль.

Лучшим оказался вариант при использовании для подкормки микроэлементного удобрения Азосол 36 Экстра, площадь листьев составила 42,5 тыс. м²/га. При фолиарной подкормке растений яровой тритикале препаратами Азосол 36 Экстра, Мегамикс-Азот, Мегамикс-Профи и НаноКремний сорормировалась практически равноценная ассимиляционная поверхность.

Увеличение показателей фотосинтетического потенциала и чистой продуктивности по периодам роста и развития в посевах яровой тритикале проходило аналогично особенностям формирования площади листовой поверхности. Показатели фотосинтетического потенциала и чистой продуктивности по вариантам опыта колебались в пределах от 0,85 до 1,03 млн. $\mathrm{M}^{2}$ дн./га и 5,20-6,29 г/м² в сутки, контроль соответственно 0,78 млн. м $^{2}$ дн./га и 4,78 $\left\ulcorner/ \mathrm{M}^{2}\right.$ в сутки. При этом наибольшие значения данных показателей отмечены при некорневой подкормке многокомпонентным жидким удобрением с высоким содержанием микроэлементов в хелатной форме Азосол 36 Экстра. Максимальные значения фотосинтетического потенциала - 1,03 млн. м ${ }^{2}$ дн./га и чистой продуктивности фотосинтеза - 6,29 г/м² в сутки наблюдались при двукратной обработке растений в фразу кущения и колошения препаратом Азосол 36 Экстра. В вариантах с фолиарной подкормкой вегетирующих растений яровой тритикале препаратами Мегамикс-Азот, Мегамикс-Профи и НаноКремний параметры фотосинтетического аппарата и чистой продуктивности фотосинтеза были равноценными.

Урожайность представляет собой комплексный показатель, который характеризует влияние различных факторов на ростовые, формообразовательные и физиолого-биохимические процессы, происходящие в растениях за период вегетации. Урожайность зерна яровой тритикале сорта Укро в среднем за три года колебалась по вариантам опыта от 3,84 до 4,43 т/га, превышение по отношению к контролю составило 0,42-1,27 т/га (13,3-40,3 \%). При подкормке тритикале микроэлементными препаратами в фразу кущения урожайность зерна по вариантам опыта составила 3,67-3,81 т/га, при листовой подкормке в фазу колошения - 3,65-3,81 т/га, что превышает контроль соответственно на 0,51-0,65 т/га (16,1$20,1 \%)$. Наибольший урожай зерна яровой тритикале $(4,26-4,43)$ т/га получен при двукратной обработке в фразу кущения и колошения микроэлементными удобрениями, что превышает контрольный вариант на 1,12-1,27 т/га (35,1-40,3 \%). Максимальная урожайность зерна (4,43 т/га) получена при двукратной фолиарной подкормке посевов яровой тритикале в фазу кущения и колошения препаратом Азосол 36 Экстра, что превышает контроль на 1,27 т/га или $40,3 \%$. Проблема увеличения производства зерна неразрывно связана с повышением технологических свойств. Микроэлементные удобрения при фолиарной подкормке растений яровой тритикале наряду с ростом урожайности обеспечили и улучшение качества зерна (табл. 2).

Применение микроэлементных удобрений Азосол 36 Экстра, Мегамикс-Азот, Мегамикс-Профи, Цитовит и НаноКремний для фролиарной подкормки в разные фразы вегетации способствовало улучшению технологических свойств зерна яровой тритикале сорта Укро (табл. 2). Так, натура зерна в среднем за три года по вариантам опыта составила 768-796 г/л, контроль 764 г/л. При подкормке в фразу кущения натура зерна была 768-785 г/л, в фразу колошения - 774-785 г/л. Наибольшие показатели натуры зерна отмечены при двукратной подкормке в фазу кущения и колошения - 787-796 г/л, максимальные при использовании препарата Азосол 36 Экстра 796 г/л, что превышает показатели контроля на 32 г/л (18,0\%). Практически равноценные показатели натуры зерна (927 г/л) получены при двукратной некорневой подкормке посевов яровой тритикале препаратами Мегамикс-Азот и НаноКремний.

Одним из основных критериев ценности зерна и продуктов его переработки яв- 
Урожайность и технологические свойства зерна яровой тритикале при некорневой подкормке микроэлементными удобрениями (2017-2019 га.)

\begin{tabular}{|c|c|c|c|c|c|c|c|c|c|}
\hline \multirow{2}{*}{$\begin{array}{c}\text { Фактор А - } \\
\text { препарат }\end{array}$} & \multirow{2}{*}{$\begin{array}{c}\text { Фактор В - } \\
\text { фраза } \\
\text { обработки }\end{array}$} & \multirow{2}{*}{ 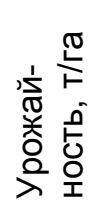 } & \multicolumn{2}{|c|}{$\begin{array}{c}\text { +/- к } \\
\text { контролю }\end{array}$} & \multirow{2}{*}{ 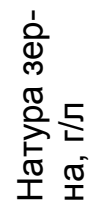 } & \multirow{2}{*}{ 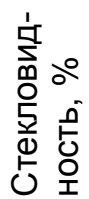 } & \multirow{2}{*}{ 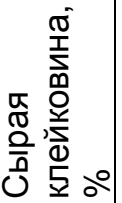 } & \multirow{2}{*}{ 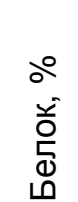 } & \multirow{2}{*}{ 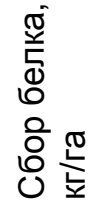 } \\
\hline & & & т/га & $\%$ & & & & & \\
\hline \multicolumn{2}{|c|}{ Без обработки (контроль) } & 3,16 & - & - & 764 & 49 & 22,5 & 11,6 & 366,6 \\
\hline \multirow{3}{*}{$\begin{array}{l}\text { Азосол } 36 \\
\text { Экстра }\end{array}$} & Кущение & 3,81 & 0,65 & 20,5 & 778 & 55 & 23,2 & 12,5 & 476,3 \\
\hline & Колошение & 3,72 & 0,56 & 17,9 & 785 & 57 & 24,8 & 13,8 & 513,4 \\
\hline & Кущение + ко & 4,43 & 1,27 & 40,3 & 796 & 63 & 26,2 & 15,1 & 668,9 \\
\hline \multirow{3}{*}{$\begin{array}{l}\text { Мегамикс- } \\
\text { Азот }\end{array}$} & Кущение & 3,73 & 0,57 & 18,2 & 770 & 54 & 23,0 & 12,4 & 462,5 \\
\hline & Колошени & 3,65 & 0,49 & 15 & 778 & 56 & 24,5 & 13,7 & 500,1 \\
\hline & Кущение + & 4,34 & 1,18 & 37, & 789 & 62 & 25,7 & 14,9 & 646,7 \\
\hline \multirow{3}{*}{$\begin{array}{l}\text { Мегамикс- } \\
\text { Профри }\end{array}$} & Кущение & 3,69 & 0,53 & 16 , & 765 & 53 & 22,8 & 12,1 & 446,5 \\
\hline & Колошение & 3,61 & 0,45 & 14,2 & 772 & 55 & 23,9 & 13,4 & 483,7 \\
\hline & Кущение + колошение & 4,30 & 1,14 & 36,1 & 783 & 59 & 24,8 & 14,3 & 614,9 \\
\hline \multirow{3}{*}{ Цитовит } & Кущение & 3,67 & 0,51 & 16,1 & 768 & 54 & 22,9 & 12,2 & 447,7 \\
\hline & Колошение & 3,58 & 0,42 & 13,3 & 774 & 55 & 24,2 & 13,6 & 486,9 \\
\hline & Кущение + ко & 4,26 & 1,12 & 35 , & 787 & 60 & 25,3 & 14,7 & 626,2 \\
\hline \multirow{3}{*}{$\begin{array}{l}\text { Нано- } \\
\text { Креммний }\end{array}$} & Кущение & 3,78 & 0,62 & 19 & 775 & 54 & 23,2 & 12,3 & 464,9 \\
\hline & Колошенv & 3,69 & 0,60 & 16,8 & 783 & 56 & 24,5 & 13,7 & 505,5 \\
\hline & Кущение + колошение & 4,38 & 1,22 & 38,6 & 793 & 61 & 25,6 & 14,9 & 652,6 \\
\hline
\end{tabular}

ляется содержание в нем белка (Н. С. Авдонин, 1960; В. Г. Минеев, 1966; А. Н. Павлов, 1992) [12, 18, 19].

Установлено, что изучаемые микроэлементные удобрения и сроки их применения оказывают неодинаковое влияние на содержание белка в зерне тритикале. Так, при проведении некорневой подкормки в фазу кущения яровой тритикале существенно повышается урожайность, однако, действие на качество зерна было выражено слабее, содержание белка в зерне в сравнении с контролем увеличилась лишь на 0,5-0,9\%. При фолиарной подкормке в более поздние фазы развития (колошения) урожайность тритикале увеличилась в меньшей степени, но содержание белка в зерне возросло по отношению к контролю на 1,8-2,2 \% и составило 13,4-13,8 \%. Наиболее эффективным приемом синтеза белка в зерне пшеницы является двукратная фолиарная подкормка микроэлементными удобрениями. При этом содержание белка в зерне по вариантам опыта составило $14,3-15,1 \%$, что превышает контроль на 2,7-3,5 \%, максимальное содержание белка в зерне 15,1\% было при использовании для подкормки препарата Азосол 36 Экстра. Сбор белка с гектара зависел от белковости зерна и урожайности. При фолиарной подкормке посевов яровой тритикале микроэлементными удобрениями сбор белка относительно контрольного показателя увеличился на 21,8-302,3 кг/га или
16,8-82,5 \%. Наибольший сбор белка с гектара 668,9 кг/га получен при двукратной подкормке препаратом Азосол 36 Экстра.

Применение микроэлементных удобрений для фолиарной подкормки способствовало повышению стекловидности зерна относительно контроля. Наилучшие показатели были получены при двукратной подкормке в фазу кущения и колошения 59$63 \%$, на контроле - $49 \%$, а максимальные - $63 \%$ при использовании препарата Азосол 36 Экстра.

При подкормке яровой тритикале комплексными микроэлементными удобрениями содержание сырой клейковины в зерне составило по вариантам опыта 22,8$26,2 \%$, контроль - 22,6\%. Наибольший показатель содержания клейковины отмечен при двукратной фолиарной подкормке в фразу кущения и колошения препаратом Азосол 36 Экстра - 26,2 \%.

\section{Заключение}

Применение микроэлементных удобрений для некорневой подкормки способствовало повышению урожайности и улучшению качества зерна яровой тритикале сорта Укро. Наибольшая урожайность зерна 4,43 т/га, прибавка - 1,27 т/га (40,3 \%) получена при двукратной некорневой подкормке в фазу кущения и колошения микроэлементным удобрением Азосол-36 Экстра, содержание клейковины увеличилось на $3,6 \%$, белка на $3,5 \%$, стекловидность на $14 \%$. 


\section{Лuтepamypa}

1. Морозов, В. И Зерновое хозяйство и его эффективность в условиях Среднего Поволжья / В. И. Морозов, С. В. Басенкова // Вестник Ульяновской ГСХА. - 2014. - № 2 (26). - С. 33-37.

2. Булавина, Т. М. Оптимизация приемов возделывания трикале в Беларуси / Т. М. Булавина // Национальная Академия Наук Беларуси, Институт земледелия и селекции НАН Беларуси; научный редактор С. И. Гриб. - Минск: ИВЦ Минфина, 2005. - 224 с.

3. Гриб, С. И. Яровое тритикале: преимущества и особенности возделывания / С. И. Гриб, Т. М. Булавина, В. Н. Буштевич // Белорусское сельское хозяйство. - 2003. - № 4. С. 24-25.

4. Гужов, Ю. Л. Тритикале - первая зерновая культура, созданная человеком / Ю. Л. Гужов. Москва: Колос, 1978. - 285 с.

5. Шулындин, А. Ф. Биологические основы агротехники и семеноводства тритикале / А. Ф. Шулындин // Сельскохозяйственная биология. 1979. - Т. 14. - Вып. 3. - С. 12-19.

6. Пейве, Я. В. Агрохимия и биохимия микроэлементов / Я. В. Пейве - Москва: Наука, 1980. $430 \mathrm{c}$.

7. Школьник, М. Я. Микроэлементы в жизни растений / М. Я. Школьник // Ленинград: Наука, 1974. -323 c.

8. Муромцев, Г. С. Основы химической регуляции роста и продуктивности растений / Г. С. Муромцев, Д. И. Чкаников, О. Н. Кулаева. - Москва: Агропромиздат, 1987. - 383 с.

9. Никкел, Л. Д. Регуляторы роста растений / Л. Д. Никел. - Москва: Колос, 1984. - 191 с.

10. Мацков, Ф. Ф. Некорневое питание растений / Ф. Ф. Мацков - Киев, 1957. - 263с.

11. Самохвалов, Г. К. Минеральное питание, как фрактор индивидуального развития растений. - Харьков: Издательство Харьковского университета, 1955. - 187 с.

12. Авдонин Н. С. Подкормка сельскохозяйственных растений / Н. С. Авдонин. - Ленинград: Сельхозгиз, 1960. - С.13-26.

13. Доспехов, Б. А. Методика полевого опыта с основами статистической обработки результатов исследований / Б. А. Доспехов. - Москва: Агропромиздат, 1985. - 351 с.

14. Ничипорович, А. А. Важнейшие проблемы фотосинтеза в растениеводстве / А. А. Ничипорович. Москва: Колос, $1970 .-320$ с. $148 \mathrm{c}$

15. Ничипорович, А. А. Фотосинтез и урожай / А. А. Ничипорович // Москва: Знания. 1966. -

16. Тооминг, Х. Г. Солнечная радиация и формирование урожая. - Ленинград: Гидрометеоиздат, 1977. - 200 c.

17. Шатилов, И. С. Фотосинтетический потенциал и чистая продуктивность клевера красного в полевых условиях. Вып. 4. / И. С. Шатилов, Г. С. Голубева. - Москва: Изд-во ТСХА, 1969. - С. 85-92.

18. Минеев, В. Г. Пути улучшения качества зерна пшеницы / В. Г. Минеев - Воронеж: Центрально-черноземное книжное издательство, 1971. - С. 41-42.

19. Павлов, А. Н. Качество клейковины пшеницы и факторы ее, определяющие / А. Н. Павлов // Сельскохозяйственная биология. - 1992. - № 1. С. 3-15.

20. Joshida Shoichi. Chemical aspects of the role of silicon in physiology of the rice plant. Bull. Nat. Inst. Agric. Sci, series B, 1965, Xol5. p. 1173-1176.

21. Nonaka, K Available silicates in paddy soils / K. Nonaka, K. Jakahashi // Bulletin - Idaho Agricultural Experiment Station. 1986. № 47. p. 2-37.

22. Triticale in France / A. Bouguennec, M. Bernard, L. Jestin, M. Trottet, P. Lonnet // Triticale improvement and production. Rome. 2004. - P. 109-114.

23. Macas, B. Triticale in Portugal / B. Macas // Triticale improvement and production. Rome, 2004. - P. 135-137.

UDC 633.112.9+631.81.095.337

DOI 10.36461/NP.2020.54.1.005

\section{EFFICIENCY OF FOLIAR DRESSING WITH MICRO-ELEMENT FERTILIZERS ON CROP AND QUALITY OF GRAIN OF SPRING TRITICALE}

A. N. Kshnikatkina, Doctor of Agricultural Sciences, Professor; A. N. Dolzhenko, post-graduate

Federal State Budgetary Educational Institution of Higher Education Penza State Agrarian University, Russia, t. (8412)62-81-51; e-mail: pererabotka_tehfak@mail.ru

The results of studies on the influence of microelement fertilizers on the formation of productivity and grain quality of spring triticale of the Ukro variety are presented. It was found that microelement fertilizers Azosol 36 Extra, Megamix-Azot, Megamix-Profi, Tsitovit and NanoKremny provided an increase in the parameters of photosynthesis of agrocenoses of spring triticale. 
The maximum value of the leaf surface of 42.5 thousand $\mathrm{m}^{2} / \mathrm{ha}$, the photosynthetic potential of 1.03 million $\mathrm{m}^{2} \mathrm{~d} / \mathrm{ha}$, the net productivity of photosynthesis of $6.29 \mathrm{~g} / \mathrm{m}^{2}$ per day were noted with double foliar dressing during the tillering and heading phases with Azosol 36 Extra. Due to the application of foliar dressing with microelement fertilizers in chelated form, an increase in the yield of spring triticale of the Ukro variety was observed, together with an improvement in the technological properties of grain. According to the experimental variants, on average for three years, the grain yield was $3.84-4.43 \mathrm{t} / \mathrm{ha}$. The increase in relation to the control ranged from 0.42-1.27 t/ha (13.3-40.3\%). The highest yield of highquality grain of $4.43 \mathrm{t} / \mathrm{ha}$ was obtained by double top dressing at the tillering and heading phases with the use of Azosol 36 Extra; an increase in grain yield was $1.27 \mathrm{t} / \mathrm{ha}(40.3 \%)$, grain unit - $796 \mathrm{~g} / \mathrm{l}$, glassiness - $63 \%$, raw gluten $-26.2 \%$, protein $-15.1 \%$.

Key words: spring triticale, microelement fertilizers, photosynthesis, yield, technological properties of grain.

\section{References:}

1. Morozov, V. I. Grain farming and its effectiveness in the Middle Volga / V.I. Morozov, S. V. Basenkova // Vestnik of Ulyanovsk state agricultural academy. - 2014. - № 2 (26). - p. 33-37.

2. Bulavina, T. M. Optimization of triticale cultivation techniques in Belarus / T. M. Bulavina // National Academy of Sciences of Belarus, Institute of Agriculture and Breeding, National Academy of Sciences of Belarus; scientific editor S. I. Grib. - Minsk: ICC of Ministry of Finance, 2005.- 224 p.

3. Grib, S. I. Spring triticale: advantages and features of cultivation / S. I. Grib, T. M. Bulavina, V. N. Bushtevich // Belarusian Agriculture. - 2003. - № 4. p. 24-25.

4. Guzhov, Yu. L. Triticale - the first grain crop created by man / Yu. L. Guzhov. - Moscow: Kolos, 1978. -285 p.

5. Shulyndin, A. F. Biological fundamentals of agrotechnology and seed production of triticale / A. F. Shulyndin // Agricultural biology. 1979. - v. 14. - Issue. 3. - p. 12-19.

6. Peive, Ya. V. Agrochemistry and biochemistry of microelements / Ya. V. Peive - Moscow: Nauka, 1980. $-430 \mathrm{p}$.

7. Shkolnik, M. Ya. Trace elements in plant life / M. Ya. Shkolnik // Leningrad: Nauka, 1974. - 323 p.

8. Muromtsev, G.S. Fundamentals of chemical regulation of plant growth and productivity $/$

G. S. Muromtsev, D. I. Chkanikov, O. N. Kulaeva. - Moscow: Agropromizdat, 1987. - 383 p.

9. Nickell, L. G. Plant Growth Regulators / L. G. Nickell - Moscow: Kolos, 1984. - 191 p.

10. Matskov, F. F. Foliar nutrition of plants / F. F. Matskov - Kiev, 1957. - 263p.

11. Samokhvalov, G. K. Mineral nutrition as a factor in the individual development of plants. Kharkov: Kharkov University Press, 1955. - $187 \mathrm{p}$.

12. Avdonin, N. S. Fertilizing agricultural plants / N. S. Avdonin. - Leningrad: Selkhozgiz, 1960. p.13-26.

13. Dospekhov, B. A. Methods of field experiment with the basics of statistical processing of research results / B. A. Dospekhov. - Moscow: Agropromizdat, 1985. - 351 p.

14. Nichiporovich, A. A. The most important problems of photosynthesis in crop production / A. A. Nichiporovich. Moscow: Kolos, 1970. -320 p.

15. Nichiporovich, A. A. Photosynthesis and harvest / A. A. Nichiporovich // Moscow: Znaniya. 1966. $-148 \mathrm{p}$.

16. Tooming, H. G. Solar radiation and crop formation. - Leningrad: Gidrometeoizdat, 1977. - 200 p.

17. Shatilov, I. S. Photosynthetic potential and net productivity of red clover in the field. Issue 4. I

I. S. Shatilov, G. S. Golubeva. - Moscow: Publishing House of the TAA, 1969. - p. 85-92.

18. Mineev, V. G. Ways to improve the quality of wheat grain / V. G. Mineev - Voronezh: Central'nochernozemnoe knizhnoe izdatel'stvo, 1971. - p. 41-42.

19. Pavlov, A. N. The quality of wheat gluten and its determining factors / A. N. Pavlov // Agricultural Biology. - 1992. - № 1. p. 3-15.

20. Joshida Shoichi. Chemical aspects of the role of silicon in physiology of the rice plant. Bull. Nat. Inst. Agric. Sci, series B, 1965, Vol 5, p. 1173-1176.

21. Nonaka, K Available silicates in paddy soils / K. Nonaka, K. Jakahashi // Bulletin - Idaho Agricultural Experiment Station. 1986. № 47. - p. 2-37.

22. Triticale in France / A. Bouguennec, M. Bernard, L. Jestin, M. Trottet, P. Lonnet // Triticale improvement and production. Rome. 2004. - p. 109-114.

23. Macas, B. Triticale in Portugal / B. Macas // Triticale improvement and production. Rome, 2004. - p. 135-137. 